\title{
Distributed specific sediment yield estimations in Japan attributed to extreme-rainfall-induced slope failures under a changing climate
}

\author{
K. Ono ${ }^{1}$, T. Akimoto ${ }^{1}$, L. N. Gunawardhana ${ }^{1}$, S. Kazama ${ }^{1}$, and S. Kawagoe ${ }^{2}$ \\ ${ }^{1}$ Department of Civil Engineering, Tohoku University, 6-6-06, Aramaki aza aoba, Aoba ku, Sendai, 980-8579, Japan \\ ${ }^{2}$ Division of Environmental System Management, Faculty of Symbiotic Systems Science, Fukushima University, 1, \\ Kanayagawa, Fukushima, 960-1296, Japan
}

Received: 4 August 2010 - Published in Hydrol. Earth Syst. Sci. Discuss.: 22 September 2010

Revised: 4 January 2011 - Accepted: 16 January 2011 - Published: 20 January 2011

\begin{abstract}
The objective of this study was to estimate the potential sediment yield distribution in Japan attributed to extreme-rainfall-induced slope failures in the future. For this purpose, a regression relationship between the slope failure probability and the subsequent sediment yield was developed by using sediment yield observations from 59 dams throughout Japan. The slope failure probability accounts for the effects of topography (as relief energy), geology and hydroclimate variations (hydraulic gradient changes due to extreme rainfall variations) and determines the potential slope failure occurrence with a $1-\mathrm{km}$ resolution. The applicability of the developed relationship was then validated by comparing the simulated and observed sediment yields in another 43 dams. To incorporate the effects of a changing climate, extreme rainfall variations were estimated by using two climate change scenarios (the MRI-RCM20 Ver.2 model A2 scenario and the MIROC A1B scenario) for the future and by accounting for the slope failure probability through the effect of extreme rainfall on the hydraulic gradient. Finally, the developed slope failure hazard-sediment yield relationship was employed to estimate the potential sediment yield distribution under a changing climate in Japan.
\end{abstract}

Time series analyses of annual sediment yields covering 15-20 years in 59 dams reveal that extreme sedimentation events have a high probability of occurring on average every 5-7 years. Therefore, the extreme-rainfall-induced slope failure probability with a five-year return period has a statistically robust relationship with specific sediment yield observations (with $r^{2}=0.65$ ). The verification demonstrated that the model is effective for use in simulating specific sediment yields with $r^{2}=0.74$. The results of the GCM scenarios suggest that the sediment yield issue will be critical

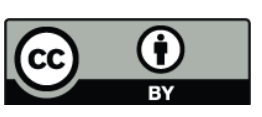

Correspondence to:

L. N. Gunawardhana

(luminda@kaigan.civil.tohoku.ac.jp) in Japan in the future. When the spatially averaged sediment yield for all of Japan is considered, both scenarios produced an approximately $17-18 \%$ increase around the first half of the 21 st century as compared to the present climate. For the second half of the century, the MIROC and MRIRCM20 scenarios predict increased sediment yields of $22 \%$ and $14 \%$, respectively, as compared to present climate estimations. On a regional scale, both scenarios identified several common areas prone to increased sediment yields in the future. Substantially higher specific sediment yield changes (over $1000 \mathrm{~m}^{3} / \mathrm{km}^{2} /$ year) were estimated for the Hokuriku, Kinki and Shikoku regions. Out of 105 river basins in Japan, 96 will have an increasing trend of sediment yield under a changing climate, according to the predictions. Among them, five river basins will experience an increase of more than $90 \%$ of the present sediment yield in the future. This study is therefore expected to guide decision-makers in identifying the basins that are prone to sedimentation hazard under a changing climate in order to prepare and implement appropriate mitigation measures to cope with the impacts.

\section{Introduction}

The latest report from the Intergovernmental Panel on Climate Change (IPCC AR4 by Parry et al., 2007) along with many other studies predicts increases in the frequency and intensity of heavy rainfall in high-latitude areas under enhanced greenhouse conditions (Jones and Reid, 2001; Palmer and Raisanen, 2002; Fowler et al., 2005). Several studies in Japan have supported this conclusion by illustrating longterm increases in rainfall intensity (Iwashima and Yamamoto, 1993; Kajiwara et al., 2003) and frequency (Suzuki, 2004) in the 20th century and by also predicting increases in the total rainfall amount by the end of the 21st century (Gunawardhana and Kazama, 2009a).

Published by Copernicus Publications on behalf of the European Geosciences Union. 
Slope failures, debris flows, and mass movements might be some of the most devastating outcomes associated with extreme rainfall (Cheng et al., 2005; Crosta and Frattini, 2008). The rapid buildup of pore water pressure beyond hydrological thresholds following extreme rainfall events can induce substantial increases in sediment yields through slope failure, resulting in enormous economical and environmental damage. Economically, extreme rainfall events bringing large quantities of sediment can push many structures, including hydro-power plants, sabo dams, urban drainage facilities, flood barriers, and other infrastructure facilities, to failure (Kunkel et al., 1999; IADB, 2000). Moreover, high sediment concentrations added to rivers and streams can degrade the drinking water quality, thus increasing the cost of water treatment, and are harmful to certain species of fish and aquatic organisms (Waters, 1995).

Japan is a country that is particularly prone to slope failures due to its steep terrains and weak geological formations. For example, extreme meteorological events in 2004 caused 326 deaths (3.4 times more than the average for 2000 2003) and resulted in damage cost of an estimated 287.5 billion JPY to agricultural production (2.7 times higher than the average for 2000-2003). The number of annual average slope failure events has doubled to more than 2530 throughout Japan (Climate Change Monitoring Report, 2004, 2005). Consequently, increased sediment concentrations have been reported, which have had an impact on river water quality and associated ecosystems over a considerably long period of time. For example, following heavy rainfall events in July 2004 in Fukui prefecture, an elevated turbidity concentration of over 100 degrees (Japanese standard for turbidity for drinking water is 2 NTU) was recorded for over five months in the Managawa dam area (Sakamoto, 2008).

In response to the increasing evidence of impacts, sediment transport attributed to extreme rainfall has become an important issue under changing climate conditions, although the cause and effect of this phenomenon have still not been practically proven. By identifying and mapping the areas prone to slope failure, the spatial distribution of this hazard can be assessed. Moreover, by linking the probability of extreme rainfall events in the past with the output of General Circulation Models (GCM), we can create climate hazard maps for the future. There have already been several studies accounting for the effects of climate changes and land use changes on sediment yields (Borga et al., 2002; Asselman et al., 2003; Philip et al., 2009). However, thus far, studies have considered only geological and geographical conditions as the triggering parameters related to the effects of time-averaged climate change scenarios. There has been no research to assess the regional-scale sediment yield attributed to extreme rainfall under changing climate conditions. Therefore, the objective of this study is to estimate the spatially distributed sediment yield attributed to extremerainfall-induced slope failure hazards under changing climate conditions for all of Japan. Given the socio-economic and ecological importance of this issue, zones must be defined in terms of the probability of occurrence of slope failures and subsequent sediment production for particular return periods. Such information will be essential for the decision-making process in Japan for hazard mitigation through proper regional planning and implementation.

\section{Methodology}

In general, there are three basic approaches, i.e., qualitative methods, physically based deterministic methods, and statistical methods, that have long been used for evaluating rainfall-induced slope failure hazards (Xie et al., 2007; Yilmazer et al., 2007; Westen et al., 2003; Temesgen et al., 2001) and corresponding sediment yield estimations (Wicks and Bathurst, 1996; Bemporad et al., 1997; Westen et al., 1999; Bathurst, 2002, Maoa et al., 2009). All of these methods have unique advantages when employed in different conditions and also suffer from their own drawbacks. The qualitative approaches are simple and easy to apply but fail to properly represent hydro-geological processes. In contrast, physically based deterministic methods systematically approximate physical concepts such as the equilibrium of the slope stability and surface water infiltration by applying a set of mathematical formulae, and modeling is done by using physically meaningful parameter set (Gunawardhana and Kazama, 2009b). The model calibration and validation is therefore carried out with comparatively short time series of field measurements. However, these methods are computationally expensive and demand reasonably accurate spatially distributed parameters and meteorological inputs at a fine resolution (Hutchinson, 1995; Guzzetti et al., 2005). Therefore, physically based deterministic methods are difficult to apply practically over large areas with complex topography and geological formations. Statistical methods, on the other hand, do not require such large amounts of detailed input data. They develop a statistical relationship between the impacts (e.g., sediment yield) and impact-triggering parameters (e.g., extreme rainfall, earthquakes) based on a series of past observations. The statistical methods therefore possess a unique advantage over the other methods because they can be applied at the regional scale (Shou et al., 2009). Moreover, they can be used to predict the susceptibility of the impact, which enables us to link the model with climate change studies. In this study, we employed statistical methodology to relate extreme-rainfall-induced slope failures with the subsequent sediment yield. The working procedure of the study includes:

1. Use of the probability model developed by Kawagoe et al. (2010) for the relationship between the slope failure hazard and triggering parameters, including spatially distributed extreme rainfall, 
2. Development of a regression relationship between the probability of slope failure and subsequent sediment yield and

3. Application of the relationships developed with selected GCM scenarios to estimate the resultant sediment yield under changing climate conditions.

Numerous studies have pointed out the importance of various processes, such as geographical, geological and hydrological processes, in rainfall-induced slope failures and sediment yield assessments (Hutchinson, 1995; Dai et al., 2001). In this study, we consider three important triggering parameters; (1) the hydraulic gradient represents the hydro-climate effect, (2) the relief energy represents the geographical effect and (3) four geological formations represent the geological effect, attributed to slope failure hazards.

Regardless of the lithological structure, slope failures are more potentially causative in steep terrains than in gentle gradients. Therefore, the relief energy, which is defined as the elevation difference between the highest and lowest point in each grid cell, was used to represent the effect of geography on slope failure hazards. The NationalLand Information Database (2001), which has well-detailed, fine-resolution $(1 \mathrm{~km} \times 1 \mathrm{~km})$, digital elevation model data (KS-META-G05-54M) for all of Japan, was used to estimate the representative relief energy for each grid cell. The same database (KS-META-G05-56M) was used to classify the area for different geological zones at the same grid resolution. There are four geological formations that are commonly found in Japan: colluviums, Neogene sedimentary rocks, Paleogene sedimentary rocks and granites; these were considered based on their likelihood in the formation of slope failures.

\subsection{Estimation of the hydraulic gradient}

The hydraulic gradient is defined as the rate of hydraulic head change per unit distance in a particular direction. Temporal changes in hydrological conditions (changes in soil moisture content from unsaturated to saturated and vice versa) due to variations in extreme rainfall and the resulting infiltration rate have an intensive impact on slope failure formations. The unsteady nature of this parameter offers a unique opportunity to combine our assessments with climate change studies. Nevertheless, it requires a large computational effort as compared to other triggering parameters. To estimate the hydraulic gradient attributed to extreme rainfall at a $1-\mathrm{km}$ resolution, we followed the method previously developed by Kawagoe et al. (2010). The two-dimensional form of Richard's equation was employed to obtain the hydraulic gradient, which was numerically solved by considering soil data, the slope angle and extreme rainfall as the independent input variables in each grid cell (more details can be found in Kawagoe et al., 2010). To estimate extreme rain- fall events, 24-hour maximum rainfall data covering 21 years (1980-2000) from the Automated Meteorological Data Acquisition System (AMeDAS) were employed with the Generalized Extreme Value (GEV) probability distribution function. For 1024 AMeDAS meteorological stations throughout Japan, GEV analysis indipendently generates 1024 extreme rainfall values to each station. Considering the fact that the rainfall patterns in mountain areas are largely influenced by irregular topography (Buytaert et al., 2006), to distribute the estimated extreme rainfall at a resolution of 1$\mathrm{km}$, we used the "Mesh Climate Data 2000" rainfall database developed by the Japanese Meteorological Business Support Center (2002). In this database, the rainfall distribution over Japan was estimated by regression models constructed using independent variables developed from geographical factors (Lookingbill and Urban, 2003; Ueyama, 2004). The data set includes the monthly averaged rainfall over 30 years (19712000 ) assembled at a $1-\mathrm{km}$ grid resolution. A relationship between the estimated extreme rainfall and maximum monthly rainfall from the Mesh Climate Data 2000 was developed for distributing the extreme rainfall to a $1-\mathrm{km}$ grid resolution. To develop a statistically better relationship, the AMeDAS stations were categorized into three seasonal classes, winter (December-February), spring-summer (March-August) and autumn (September-November) based on the probability of an extreme rainfall event. As an example, the mountain areas at the seaside receive their maximum rainfall during the winter, while the south islands of Japan receive the most rainfall in the spring-summer category (Kawagoe et al., 2010). Therefore, three separate regression analyses were performed to obtain the relationship between the extreme rainfall and maximum monthly rainfall from the Mesh Climate Data 2000, and later extreme rainfall values were distributed with a 1-km grid resolution based on the maximum monthly rainfall values from the Mesh Climate Data 2000 at each grid box. These extreme rainfall values were then used as the main input in the infiltration analysis to find the hydraulic gradients.

\subsection{Probability model for slope failure}

By following the above procedures, the probability of slope failure occurrence was determined by accounting for past events of slope failures at each grid cell. A stepwise logistic regression method was then employed to find the relationship between the triggering parameters and slope failure probability (Eq. 1). Instead of considering the geological type as an independent variable with the appropriate weighting factor in the model, four different models were developed for each geological type.

$$
\begin{aligned}
& \log \left(\frac{P}{1-P}\right)=\sigma_{0}+\sigma_{h} \times h y d+\sigma_{r} \times \text { relief } \\
& P=\frac{1}{1+\exp \left[-\left(\sigma_{0}+\sigma_{h} \times h y d+\sigma_{r} \times \text { relief }\right)\right]}
\end{aligned}
$$


where $P$ is the probability of slope failure occurrence, $\sigma_{0}$ is the intercept, $\sigma_{h}$ is the coefficient of the hydraulic gradient, $\sigma_{r}$ is the coefficient of relief energy, hyd is the hydraulic gradient, and relief is the relief energy.

\subsection{Probability model for sediment yield}

Many studies have derived magnitude-frequency relationships for sediment yields in hazard assessments (Helsen et al., 2002; Marchi et al., 2002, Hunger et al., 2008). Differences among these relationships reflect the influence of triggering parameters, such as rainfall, and the geomorphologic setting of the catchments. In this study, we developed a relationship between the annual average specific sediment yield and the average probability of slope failure in the representative catchment. The annual sediment yield data are available for the public use in the data base of Ministry of Land, Infrastructure, Transport and Tourism (MLIT) in Japan, where Sediment depth were measured by the automatic sensors, and used with the available cross-sections of the basin to calculate the annual average specific sediment yields. All selected dams are located in the upstream of the rivers, where the catchment area is largely cover with forest. According to Hasegawa et al. (2005), higher plant density in Japanese forest prevents excessive sediment erosion by normal rainfall events. Therefore, the effect of soil erosion on sediment accumulation is quite small compared to large sediment yield produced by slope failures. Altogether, 59 dams were selected throughout Japan. For each of these dams, the catchment areas are larger than $185 \mathrm{~km}^{2}$ and more than 15 years of annual sediment yield records are available. The same relationship was developed for various return periods of extreme rainfall, and the goodness of the fit was evaluated against the coefficient of determination to select the best-fit relationship for climate predictions.

\subsection{GCMs for climate predictions}

The Special Report on Emission Scenarios (SRES) along with the IPCC AR4 report has given widely recognized GCMs for climate predictions. In this study, we used two climate scenarios from two GCMs developed in Japan: the Meteorological Research Institute Regional Climate model (MRI-RCM20-Ver.2) embedded with the SRES A2 scenario and the MIROC3.2_HIRES (high-resolution version of the Model for Interdisciplinary Research on Climate) embedded with the SRES A1B scenario. The GCMs above have demonstrated good performance in simulating large-scale circulations and climate features that affect regional climates (Salathe et al., 2007). However, the resolutions are still far too coarse to use in site-specific assessments, especially in mountainous areas. Therefore, a statistical downscaling technique was employed to link the spatial gap between the local scale grid resolution (1-km in this study) and the GCM grid scale (Iizumi et al., 2008). Climates for three time periods, the present climate (1980-2000), an intermediate climate (2036-2065 for MIROC and 2031-2050 for MRI-RCM20Ver.2) and the future climate (2065-2095 for MIROC and 2081-2100 for MRI-RCM20-Ver.2), were selected to show the transition of the impact in the future. The two selected GCMs have some advantages as compared to other models presented in IPCC AR4. Firstly, the model outputs produced finer resolutions, which is particularly useful for use with mountainous topography. For example, the HADCM3 model has a very coarse resolution that is approximately equal to $90465 \mathrm{~km}^{2}$ of the grid boxes in Japan, while the MRIRCM20-Ver. 2 model resolution is only $400 \mathrm{~km}^{2}$. Secondly, MIROC and MRI-RCM20-Ver. 2 have been proven to be very effective in simulating the climate variables that eventually produced the impacts for extreme cases over wider ranges (GERF S-4 project document, 2008). Therefore, they avoid the extensive downscaling efforts that are necessary for many GCM scenarios for predicting the impacts in a reliable range.

In the first step of downscaling, the procedure explained in Sect. 2.1 was applied with the GCM-produced daily rainfall to obtain the extreme rainfall distribution at the GCM grid scale (hereafter referred to as $\mathrm{ERF}_{\mathrm{GCM}}$ ). Because the bias correction was to be performed at the GCM grid scale, the extreme rainfall in the present climate (hereafter referred to as $\left.E F_{P C}\right)$ as derived in Sect. 2.1 at a 1-km grid resolution was aggregated with the grid scale of the climate model (e.g., $20 \mathrm{~km}$ for MRI-RCM20-Ver.2). The $\mathrm{ERF}_{\mathrm{GCM}}$ data for each time period (intermediate and future climate) were then separately matched with the $\mathrm{ERF}_{\mathrm{PC}}$ data belonging to the three seasonal categories to form transfer functions (six transfer functions for each GCM scenario separated into three seasonal classes and two time resolutions). In the final step, the original extreme rainfall values at a 1-km grid resolution were used in the corresponding transfer function to obtain the future (intermediate and future climate) extreme rainfall values. This process was repeated for each grid cell in the domain to obtain the extreme rainfall distribution for two scenarios in two future time periods.

\section{Results and discussion}

\subsection{Slope failure probability and sediment yield}

The spatial distribution of sediment yield in Japan attributed to extreme-rainfall-induced slope failure probability was estimated. In the first stage of the research, the spatial distribution of the slope failure probability was estimated by considering the extreme-rainfall-induced hydraulic gradient, relief energy and geological formation as the triggering parameters. The results portrayed two distinct aspects of the slope failure probability (Table 3 in Kawagoe et al., 2010). Firstly, the calculated standardized partial regression coefficient produced noticeably different values for the two triggering parameters. This coefficient explains the change in slope failure 


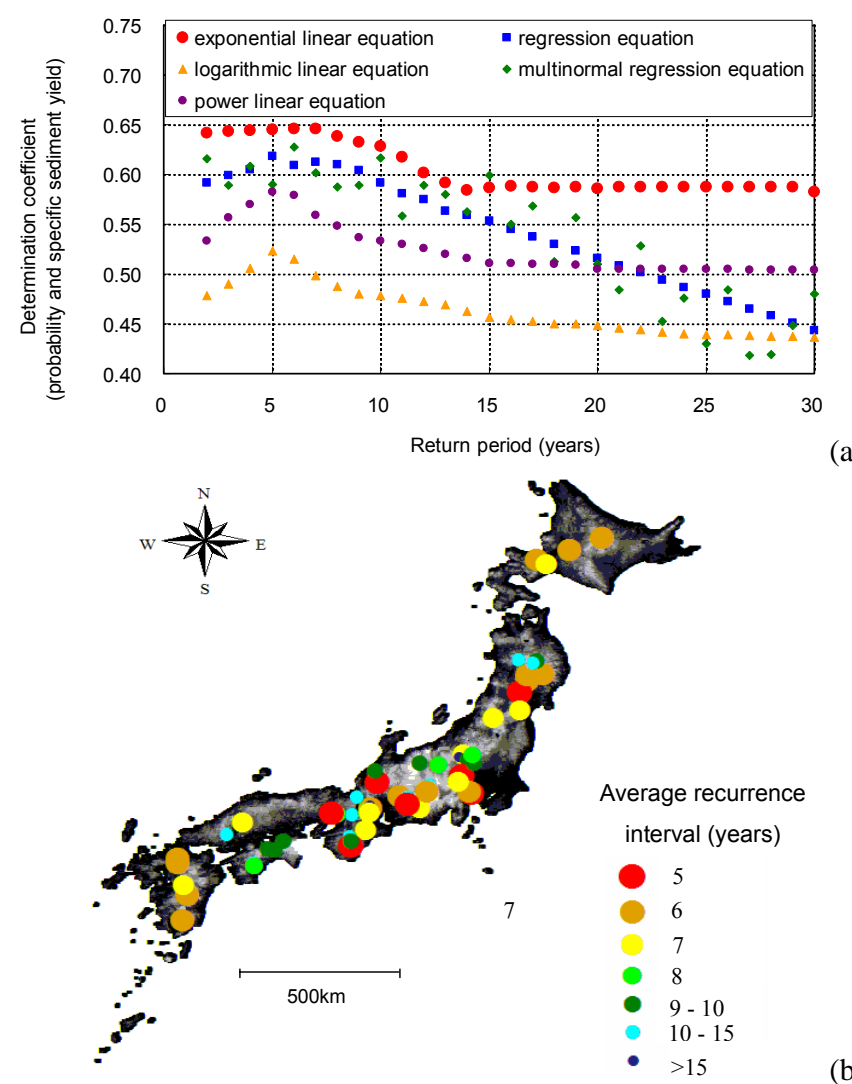

(b)

Fig. 1. (a) Determination coefficient of probability of the slope failure and specific sediment yield with respect to different return periods, (b) return period of extreme sediment yield events.

probability in the model when one triggering parameter (hydraulic gradient or relief energy) is changed by one unit while the other parameter is held constant. The standardized partial regression coefficient was higher for the hydraulic gradient than for the relief energy for all four geological formations. This suggests that the hydraulic gradient is more influential than the relief energy in terms of triggering slope failures. Secondly, differences in magnitude of the coefficient of each parameter in different geological settings indicate variations in their resistance to slope failures. The probability of slope failure occurrence varied from the highest in colluviums to the lowest in granites. The generally loose, non-consolidated nature of the colluviums has been proven to be more significant in the occurrence of slope failures than hard compact formations such as granite (Restrepo et al., 2006). The developed slope faliure model was validated with historical landslide hazard data for Tochio city, where 183 landslides were occurred in 2004 (Kawagoe et al., 2010). It showed that all 183 slope failures have occurred in the areas where we have estimated slope failure probability with more than $80 \%$.

In the next step, a regression model for the slope failure probability and subsequent sediment yield was developed. Extreme rainfalls generally exhibit greater return pe-

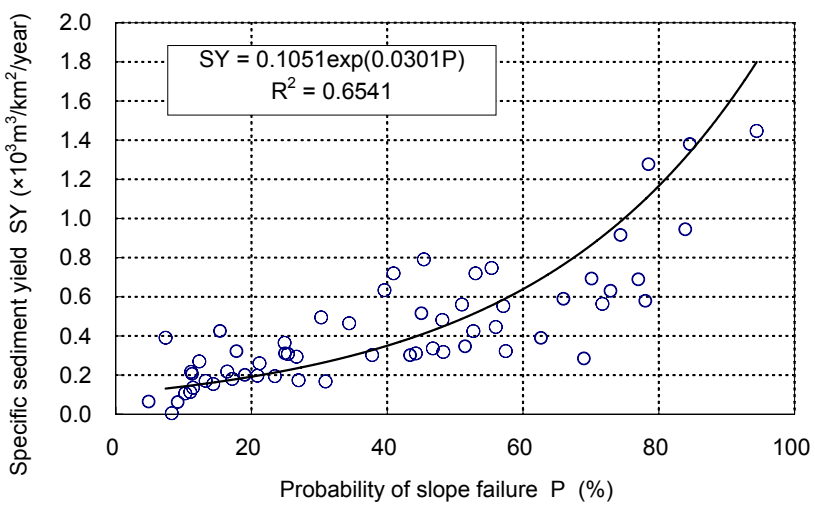

Fig. 2. Relationship between the probability of slope failure and specific sediment yield.

riods (e.g. Jones and Reid, 2001). In this study, we examined the match of various return periods of extreme rainfall (e.g. 5, 10, 15, 20, 25 and 30) with specific sediment yield. Among them, the five-year return period gave the best fit with a determination coefficient of 0.65 for exponential linear equation (Fig. 1a). The underlying reason for the best fit with respect to the five-year return period was tested by examining the number of years of extreme sediment yield in each dam. Annual sediment yield records covering 15-20 years at each dam were examined. Assuming that the annual sediment yield averaged over the catchment is normally distributed throughout the recording period (15-20 years), the lower bound of the extreme sediment yield $\left(\mathrm{SY}_{\mathrm{LB}}\right.$ in $\mathrm{m}^{3} / \mathrm{km}^{2} /$ year) in each catchment is defined as in Eq. (2).

$\mathrm{SY}_{\mathrm{LB}}=\mathrm{SY}_{\mathrm{Avg}}+\mathrm{SD}$

where $\mathrm{SY}_{\mathrm{Avg}}$ (in $\mathrm{m}^{3} / \mathrm{km}^{2} /$ year ) is the annual average sediment yield in the catchment and SD is the standard deviation of the annual sediment yield data series. Sediment yields exceeding the threshold of $\mathrm{SY}_{\mathrm{LB}}$ are defined as extreme sediment yield events. The threshold of $S Y_{L B}$ is then used to separate the years with extreme sediment yield events at each dam site. Figure $1 \mathrm{~b}$ indicates the average recurrence interval (Chow et al., 1988) of extreme sediment yield events at all selected dam sites throughout Japan. According to this, over $55 \%$ of the dams studied, experience an extreme sediment yield event every 5-7 years, and over $80 \%$ of the dams experience one every 5-10 years, on average. These figures clearly explain the reason for the statistically better relationship obtained between the extreme rainfall and extreme sediment yield over a five-year return period.

Figure 2 depicts the relationship between the catchmentaveraged probability of the slope failure occurrence and the annual-averaged sediment yield for a five-year extreme rainfall return period, and Eq. (3) shows the representative regression relationship.

$\mathrm{SY}=0.1051 \exp (0.0301 P)$ 


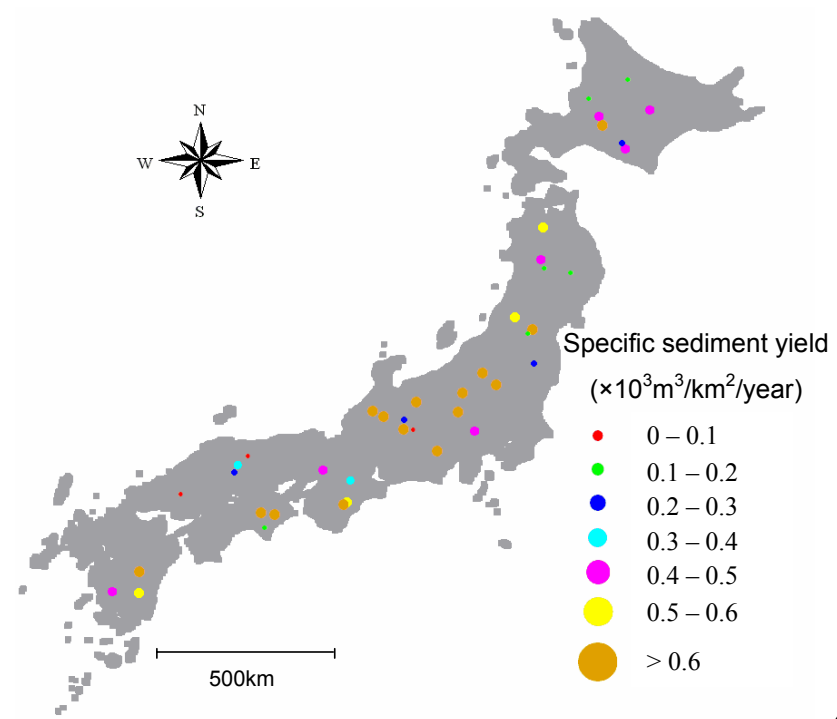

(a)

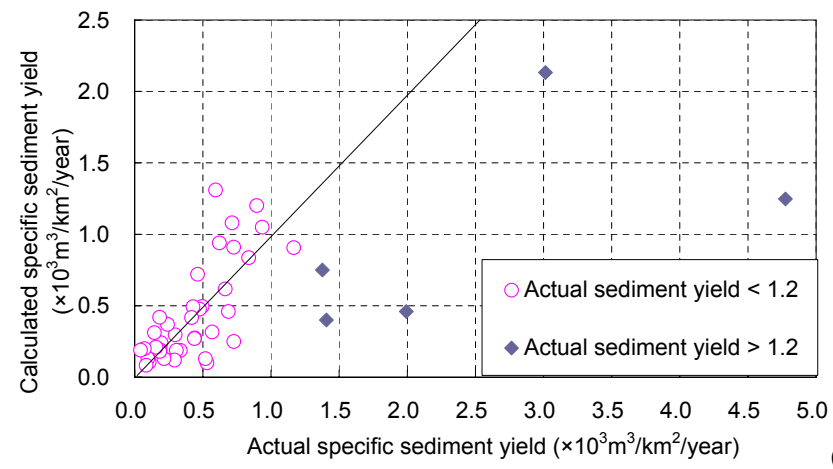

(b)

Fig. 3. Model validation: (a) locations of the selected dams, (b) observed and simulated specific sediment yields.

where SY is the annual average sediment yield $\left(\mathrm{m}^{3} / \mathrm{km}^{2} /\right.$ year) in a particular dam and $P$ is the spatially averaged probability of slope failure occurrence in a specific dam catchment. The exponential shape of the relationship indicates that the sediment yield may substantially increase with increasing probability of slope failure.

The validity of the developed relationship was tested prior to its use in climate impact predictions. Another 43 dams, which were not considered in developing the original regression relationship, were selected, covering all of Japan. Figure $3 \mathrm{a}$ shows the locations of these dams in Japan based on their annual average sediment productions. Figure $3 b$ depicts a comparison of the simulated and observed sediment yields. Out of the 43 dams, only 5 dams whose observed annual average sediment accumulations were greater than $1.2 \times 10^{3} \mathrm{~m}^{3} / \mathrm{km}^{2} /$ year were not well-predicted in terms of sediment yield. It is noted that the catchment areas of the dams with low accuracy predictions were comparatively small, and large-scale slope failures have occurred following recent extreme rainfall events. The relationship developed in Eq. (3) considered long-term sediment accumula- tions in the dams (averaged over 15-20 years). Therefore, when the sediment yield records were averaged over time, dams with recently outsized sediment accumulations eventually produced atypical average sediment yield values. Therefore, by averaging the values with a set of future sediment yield records over a wider time scale would match the sediment yield records of the five dams with the developed regression relationship. When the results of the 5 dams with excessive sediment accumulation were disregarded, the sediment yields calculated from the model indicated good agreement with the observed sediment loads in the other 39 dams, with a determinacy coefficient of 0.74 . This confirms that the relationship developed between the probability of slope failure and sediment yield can be successfully applied in longterm studies of climate change impact predictions.

The sensitivity of the sediment yield model to the triggering parameters was also tested. Figure 4 shows the variations in sediment yield with relief energy and hydraulic gradient for four selected geological formations. Similar to the slope failure probability, the sediment yield potential is highest in colluviums and decreases in the order of Neogene sedimentary rocks and Paleogene sedimentary rocks to the lowest potential in granites. As an example, for a unit change in the hydraulic gradient, colluviums formations produce $12.2 \times 10^{3} \mathrm{~m}^{3} / \mathrm{km}^{2} /$ year of sediment yield, which is $94 \%$ higher than the sediment yield production of granites under the same conditions. Similarly, Neogene sedimentary rock and Paleogene sedimentary rock produce $8.6 \times 10^{3} \mathrm{~m}^{3} / \mathrm{km}^{2} /$ year and $6.5 \times 10^{3} \mathrm{~m}^{3} / \mathrm{km}^{2} /$ year of sediment load for a unit change in the hydraulic gradient, respectively.

Figure 4 also reveals an important aspect that would be critical under changing climate conditions. The hydraulic gradient is a rainfall-sensitive parameter that can be significantly elevated with an increase in the intensity and frequency of rainfall with climate change effects. According to Fig. 4, the rate of change of the sediment yield (gradient of the curve) is more sensitive to a small change in the hydraulic gradient, especially within the rising limb of the curve (e.g., $12.2 \times 10^{3} \mathrm{~m}^{3} / \mathrm{km}^{2} /$ year per unit change of hydraulic gradient for colluvium formations). Therefore, areas that will cross the lower edge of the rising limb in the future may have a critical impact on the sediment yield under changing climate conditions.

\subsection{Spatial variability of sediment yield}

By applying the developed sediment yield model with the distributed slope failure probability, the spatial variability of the sediment yield can be estimated. Figure 5a shows the spatial distribution of the sediment yield estimated at a 1$\mathrm{km}$ grid resolution. Moreover, the model-predicted sediment yields were further aggregated to the major river basins of Japan. These river basins were categorized based on the existence of first-order rivers in Japan. Figure $5 \mathrm{~b}$ depicts the 

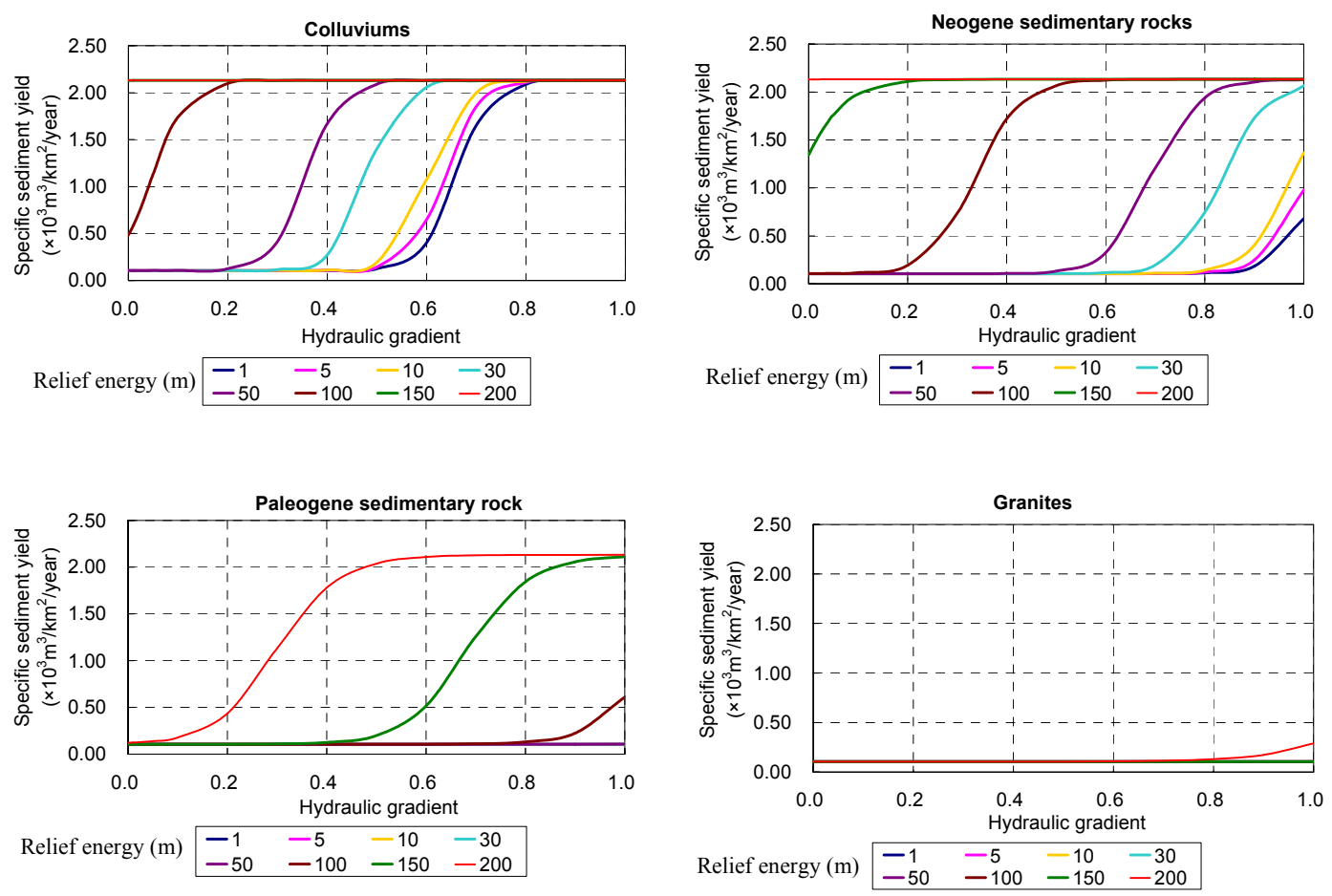

Fig. 4. Sensitivity of specific sediment yield to the triggering parameters.

average sediment yield based on the different basins. Areas with significantly higher specific sediment yields (over $2000 \mathrm{~m}^{3} / \mathrm{km}^{2} /$ year) are distributed throughout the Tenryu, Ooi and Kiso river basins in the Hokuriku and Tokai regions and the Shimanto and Naka river basins in the Shikoku region. The lithology and relief energy differences between the various regions may play an important role in producing sediment yield (Fig. 4). As an example, the greater yields corresponding to the Yoshino river basin in the Tokai region consists of $40 \%$ colluviums and $27 \%$ Neogene sedimentary rock formations, whose soils have a low resistance to the sediment yield, while granites with high resistance to the sediment yield cover only $1 \%$ of the area. Moreover, the Tohoku and Hokuriku mountain seaside regions with comparatively high relief energy have a significantly higher specific sediment yield (spatial average of $600-800 \mathrm{~m}^{3} / \mathrm{km}^{2} /$ year in Fig. 5b) as compared to areas with low relief energy, such as the eastern side of the Kanto region.

\subsection{Sediment yield distribution under changing climate conditions}

Two climate change scenarios applied to two time periods in the future produced four sets of results to demonstrate the transition of the sediment yield with climate change effects (Fig. 6). In general, all of the figures indicate several common areas with significant sediment yield changes in the future, even though the magnitudes are somewhat differ- ent. Above all, substantial specific sediment yield changes (over $1000 \mathrm{~m}^{3} / \mathrm{km}^{2} /$ year) were estimated along the mountain areas in the Hokuriku and Kinki regions. The southern Shikoku region was also predicted to have a significant specific sediment yield change, although it varies in the different figures ( 250 to over $1000 \mathrm{~m}^{3} / \mathrm{km}^{2} /$ year). Second only to the above areas, the southern Hokkaido region was predicted to have a specific sediment yield increase in the interval between 250 and $500 \mathrm{~m}^{3} / \mathrm{km}^{2} /$ year in three estimations out of four: for MIROC in intermediate and future climate and MRI-RCM20 in the intermediate climate, while MRI-RCM20 predicted an increase in the interval between 0 and $250 \mathrm{~m}^{3} / \mathrm{km}^{2} /$ year. Moreover, some areas in the Tohoku region may move from the 0 - to $250-\mathrm{m}^{3} / \mathrm{km}^{2} /$ year category to the 250 - to $500-\mathrm{m}^{3} / \mathrm{km}^{2} /$ year specific sediment yield category. In contrast, for the northern Hokkaido, northern Kyushu and Kanto regions, the model does not predict a significant sediment yield difference in the future.

Despite the approximately similar patterns of sediment yield in the above regions in our four estimations, there were marked differences at the local basin scales. These differences can be attributed to changes in extreme rainfall in the different scenarios for the different time periods. As an example, the model predictions for the Toyo river basin in the Tokai region indicate an over $70 \%$ sediment yield increment for the MIROC intermediate and future climates and for the MRI-RCM20 intermediate climate, while the MRI-RCM20 future estimations predict only a $40 \%$ increase. The same 


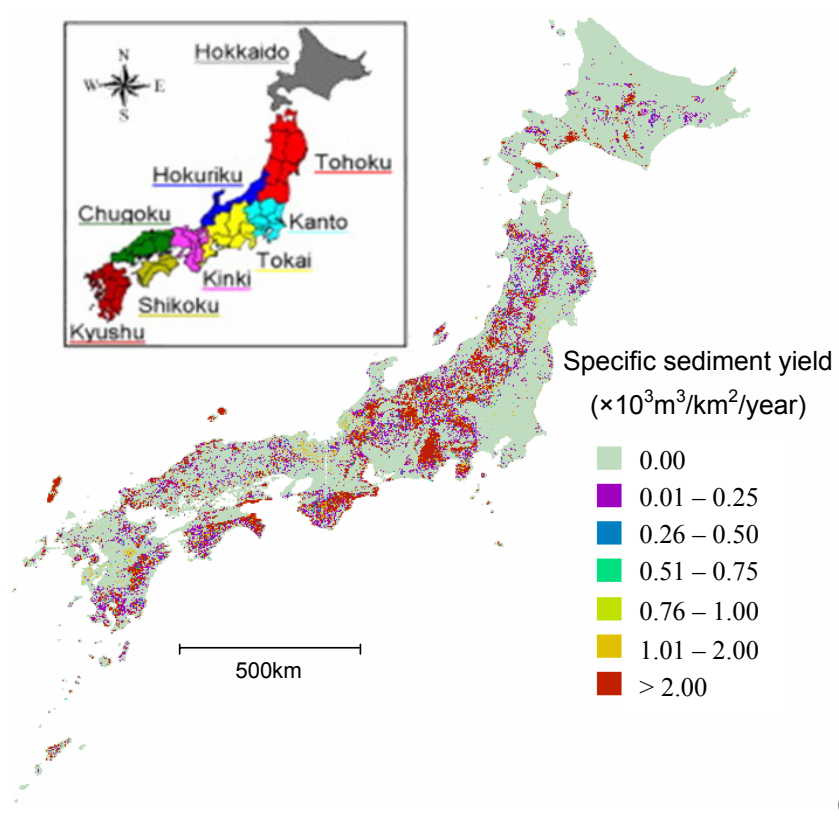

(a)

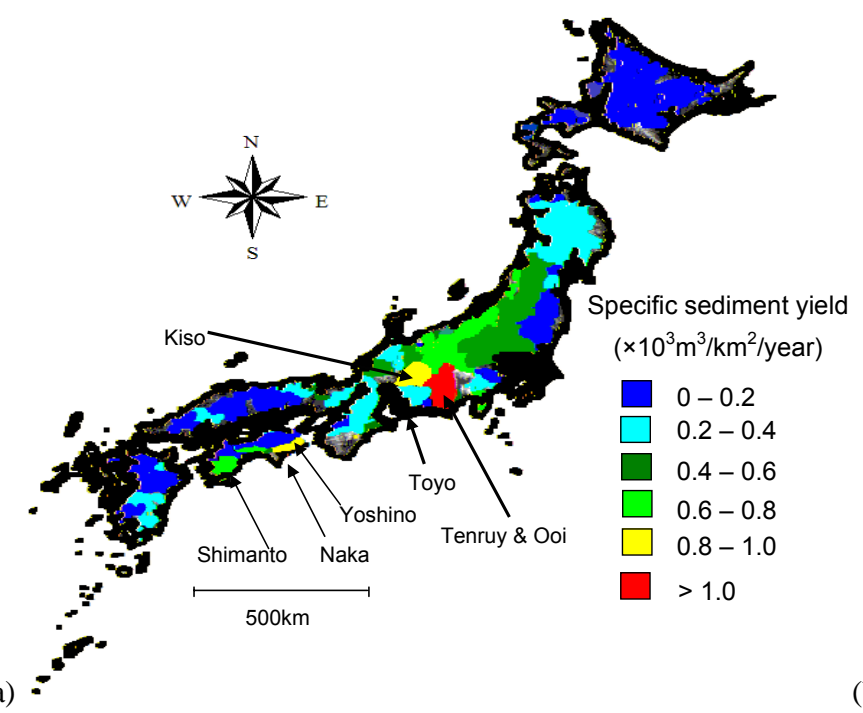

Fig. 5. Spatial distribution of specific sediment yield: (a) at a 1-km grid resolution, (b) averaged to the basin scale.

phenomenon can be observed in extreme rainfall changes in the future, where the MIROC intermediate and future climates and the MRI-RCM20 intermediate climate predicted an average extreme rainfall increase of $28 \%$, while the MRIRCM20 future estimations gave an only $8 \%$ extreme rainfall increase. Out of 105 river basins that cover the whole area of Japan, the model predicted an approximately constant or decreasing trend of sediment yield for only 9 river bains in future as compared to the present estimations. The average percentage of the sediment yield reduction in these nine river basins was less than $10 \%$, suggesting that almost all of the river basins in Japan will suffer from an increasing sediment yield risk in the future. For 15 river basins, the model predicted a more than $50 \%$ sediment yield increment in the future (for at least three out of four estimations in the future), and among them, 5 river basins will experience a more than $90 \%$ change as compared to the present sediment yield.

When looking at the spatially averaged sediment yield over the whole country, both model scenarios predicted an increasing trend for the intermediate climate (Fig. 7), implying a potential impact in the first half of the 21 st century. With respect to four future estimations for 105 river basins, the MRIRCM20 future climate, however, predicted a higher sediment yield than the other three estimations for only 8 river basins. Therefore, for the future climate, the MRI-RCM20 scenario predicted a small decreasing trend as compared to the intermediate climate, while the MIROC scenario predicted a continuously increasing trend. These changes were mainly attributed to variations in extreme rainfall events in the future and were also influenced by the geology and relief energy of each individual basin.
The estimates for the total sediment yield at the river basin scale during extreme rainfall events in the future make it easy to identify the hazard-prone areas under a changing climate conditions. By referring to our results, decision-makers can narrow down the area of interest to the specific local scales, and proper mitigation measures can be implemented with support of the respective local authorities. The errors of the model predictions that could not explain the variations of the observed sediment yield can also be attributed to the landuse-change-induced sediment yield at the very local scale. Although many studies have documented sediment yields caused by anthropogenic influences (Asselman et al., 2003; Philip et al., 2009), it is quite difficult to incorporate them into a probabilistic model in regional-scale analysis. Therefore, the inclusion of more detailed information on land use and sub-basin watershed characteristics in site-specific approaches should provide more accurate predictions. After identifying the hazard-prone basins as done in this study, such a detailed analysis would be appropriate for designing infrastructure facilities for mitigating future climate change impacts.

\section{Conclusions}

In order to facilitate the decision-making process by identifying hazard-prone areas under changing climate conditions, this study developed a probabilistic model for the relationship between the slope failure probability induced by extreme rainfall and sediment yield. There are three triggering parameters; the hydraulic gradient, the relief energy and the 


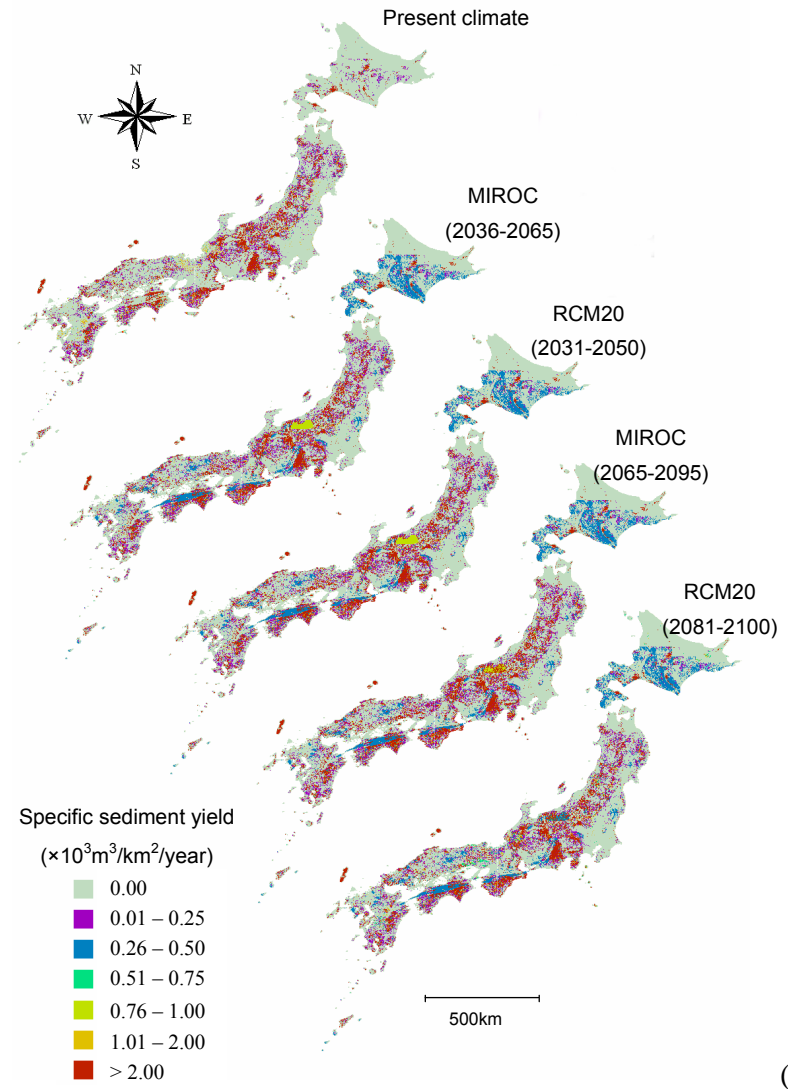

(a)

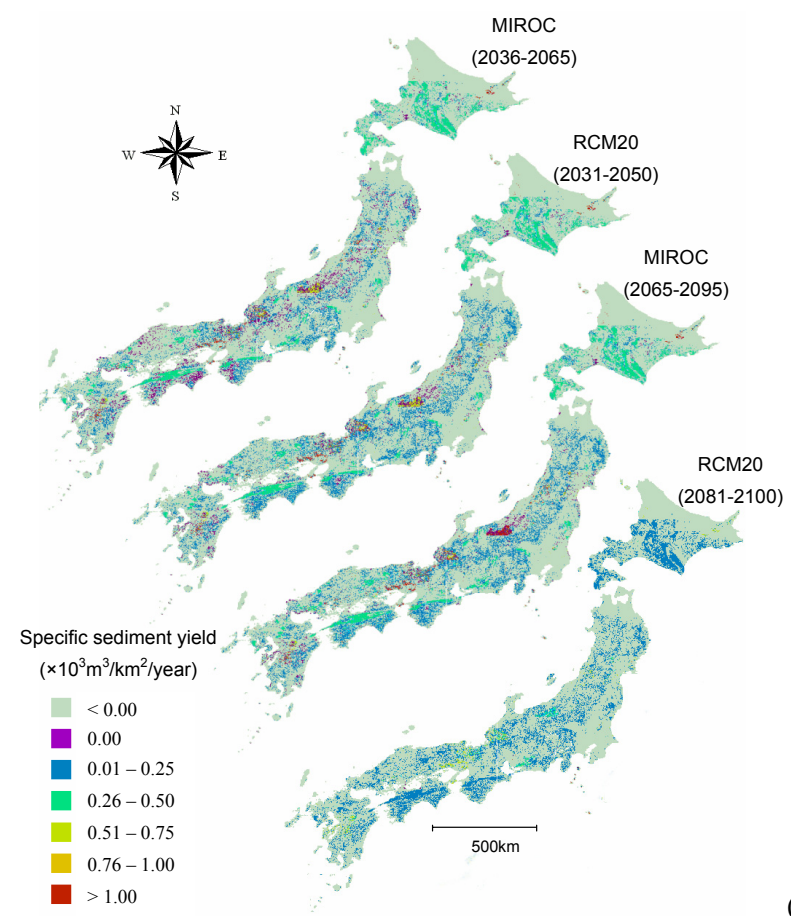

(b)

Fig. 6. Specific sediment yield distribution under a changing climate: (a) specific sediment yield for different climate change scenarios, (b) specific sediment yield change as compared to the present climate.

geology type representing the hydro-climate (hydrology and extreme rainfall), topography and geological effects, respectively, were considered in developing the probabilistic model for slope failure. The relationship between the slope failure and subsequent sediment yield was developed by matching the annual average sediment yield observations at 59 dams throughout Japan with the average probability of slope failure hazard in the representative catchment areas. For the predictions of climate change impacts, two climate model scenarios, MRI-RCM20 A2 and MIROC A1B, in two time periods (intermediate climate and future climate) in the future were incorporated.

The results show that extreme sedimentation events have a high probability of occurring every $5-7$ years. The verified results of the developed slope failure-sediment yield relationship demonstrated that the model is effective and useful in estimating the sediment yield attributed to extreme-rainfallinduced slope failure (with a determinacy coefficient equal to 0.74 ). The sensitivity analysis of the model showed that the sediment yield potential was highest in colluviums and decreased in the order of Neogene sedimentary rocks and Paleogene sedimentary rocks to the lowest potential in granites. Moreover, it is known that the hydraulic gradient is more influential than the relief energy.
The results of the GCM scenarios predict that the sediment yield impact will increase in the future. When the spatial average sediment yield for all of Japan is considered, both scenarios produced an approximately $16-17 \%$ and 14 $21 \%$ increase around the first half and second half of the 21 st century, respectively as compared to the present climate. On the regional scale, substantially higher sediment yield changes (over $1000 \mathrm{~m}^{3} / \mathrm{km}^{2} /$ year) were estimated in the Hokuriku, Kinki and Shikoku regions. The southern Hokkaido region is predicted to experience a moderate sediment yield increase $\left(250-500 \mathrm{~m}^{3} / \mathrm{km}^{2} /\right.$ year), while the Tohoku region is predicted to have a 0 - to $250-\mathrm{m}^{3} / \mathrm{km}^{2} /$ year increase in sediment yield. Due to variations in extreme rainfall events, the sediment yield estimations at the basin scale predicted changes of different magnitudes. Out of 105 basins in Japan, 96 showed an increasing trend of sediment yield under changing climate conditions. Among them, five river basins will experience a more than $90 \%$ change as compared to the present sediment yield.

Following the increasing trend of extreme meteorological events and the resulting vast impact on socio-economic and environmental sectors, decision-makers in Japan faced new challenge to implement mitigation measures under a changing climate. From the results of our study, proper 


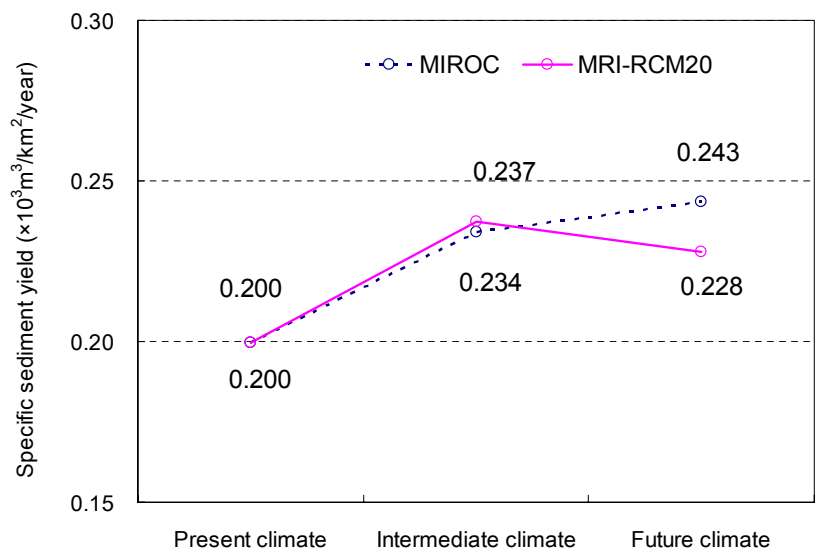

Fig. 7. Spatially averaged specific sediment yield in Japan according to different climate change scenarios.

identification of the basins that are prone to sedimentation hazards under changing climate conditions can guide decision-makers in preparing and implementing appropriate mitigation measures to cope with the impacts.

Acknowledgements. This work was supported by the Environment Research and Technology Development Fund (S-8) of the Ministry of the Environment and Grants-in-Aid for Scientific Research, Japan. The sedimentation data was provided by the Japan Water Agency (JWA) and the Ministry of Land Infrastructure, Transport and Tourism (MLIT) in Japan.

Edited by: M. Mikos

\section{References}

Asselman, N. E. M., Middlekoop, H., and Dijk, P. M.: The impact of changes in climate and land use on soil erosion, transport and deposition of suspended sediment in the River Rhine, Hydrol. Process., 17, 3225-3244, 2003.

Bathurst, J. C.: Physically-based erosion and sediment yield modelling: the SHETRAN concept. Modelling Erosion, Sediment Transport and Sediment Yield, Technical Documents in Hydrology, 60, UNESCO, 2002.

Bemporad, G. A., Alterach, J., Amighetti, F. F., Peviani, M., and Saccardo, I.: A distributed approach for sediment yield evaluation in Alpine regions, J. Hydrol., 197, 370-392, 1997.

Borga, M., Fontana, G. D., and Cazorzi, F.: Analysis of topographic and climatic control on rainfall-triggered shallow landsliding using a quasi-dynamic wetness index, J. Hydrol., 268, 56-71, 2002.

Buytaert, W., Celleri, R., Willems, P., Bievre, B. D., and Wyseure, G.: Spatial and temporal rainfall variability in mountainous areas: A case study from the south Ecuadorian Andes, J. Hydrol., 329, 413-421, 2006.

Cheng, J. D., Huang, Y. C., Wu, H. L., Yeh, J. L., and Chang, C. H.: Hydrometeorological and landuse attributes of debris flows and debris floods during typhoon, Toraji, July 29-30, 2001 in Central Taiwan, J. Hydrol., 306, 161-173, 2005.
Chow, V. T., Maidment, D. R., and Mays, L. W.: Appl. Hydrol., McGraw-Hill, Singapore, 1988.

Climate change monitoring report: Japan Meteorological Agency, 2004.

Climate change monitoring report: Japan Meteorological Agency, 2005.

Crosta, G. B. and Frattini, P.: Rainfall-induced landslides and debris flows, Hydrol. Process., 22, 473-477, 2008.

Dai, F. C., Lee, C. F., Li, J., and Xu, Z. W.: Assessment of landslide susceptibility on the natural terrain of Lantau Island, Hong Kong, Environ. Geol., 40, 381-391, 2001.

Fowler, H. J., Ekstrom, M., Kilsby, C. G., and Jones, P. D.: New estimates of future changes in extreme rainfall across the UK using regional climate model integrations. 1. Assessment of control climate, J. Hydrol., 300, 212-233, 2005.

GERF S-4 project document: Global warming impacts on Japan, latest scientific findings. The report for the comprehensive assessment of climate change impacts to determine the dangerous level of global warming and appropriate stabilization target of atmospheric GHG concentration, 2008.

Gunawardhana, L. N. and Kazama, S.: A use of global climate model output for site-specific assessment of climate change impacts on groundwater temperature, in: Trends and Sustainability of Groundwater in Highly Stressed Aquifers, 329, IAHS Publications, Wallingford, UK, 264-276, 2009a.

Gunawardhana, L. N. and Kazama, S.: Tidal effects on aquifer thermal regime: An analytical solution for coastal ecosystem management, J. Hydrol., 377, 377-390, 2009b.

Guzzetti, F., Reichenbach, P., Cardinali, M., Galli, M., and Ardizzone, F.: Probabilistic landslide hazard assessment at the basin scale, Geomorphology, 72, 272-299, 2005.

Hasegawa, K., Wakamatsu, K., and Matsuoka M.: Mapping of potential erosion-rate evaluated from reservoir sedimentation in Japan, Journal of Natural Disaster Science, 24, 287-301, 2005.

Helsen, M. M., Koop, P. J. M., and Steijn, H. V.: Magnitudefrequency relationship for debris flows on the fan of the Chalance Torrent, Valgaudemar (French Alps), Landforms, 27, 1299_ 1307, 2002.

Hungr, O., McDougall, S., Wise, M., and Cullen, M.: Magnitude frequency relationships of debris flows and debris avalanches in relation to slope relief, Geomorphology, 96, 355-365, 2008.

Hutchinson, J. N.: Landslide hazard assessment, in: Landslides, edited by: Bell, D. H., 1805-1841, 1995.

IADB (Inter-American Development Bank): Social Protection for Equity and Growth. Johns Hopkins University Press, Baltimore, 2000.

Iizumi, T., Nishimori, M., and Yokozawa, M.: Combined equations for estimating global solar radiation: Projection of radiation field over Japan under global warming condition by statistical downscaling, Journal of Agricultural Meteorology, 64, 9-23, 2008.

Iwashima, T. and Yamamoto, R.: A statistical analysis of the extreme events: long-term trend of heavy daily rainfall, Journal of the Meteorological Society of Japan, 71, 637-640, 1993.

Japanese Meteorological Business Support Center: http://www. jmbsc.or.jp/index.html, 2002.

Jones, P. D. and Reid, P. A.: Assessing future changes in extreme rainfall over Britain using regional climate model integrations, Int. J. Climatology, 21, 1337-1356, 2001.

Kajiwara, M., Oki, T., and Matsumoto, J.: Secular change in the 
frequency of heavy rainfall over Japan for 100 years, Proceedings of the 2003 spring meeting of the MSJ, 484, 2003 (in Japanese).

Kawagoe, S., Kazama, S., and Sarukkalige, P. R.: Probabilistic modelling of rainfall induced landslide hazard assessment, Hydrol. Earth Syst. Sci., 14, 1047-1061, doi:10.5194/hess-14-10472010, 2010.

Kunkel, K. E., Pielke, R. A., and Changnon, S. A.: Temporal fluctuations in weather and climate extremes that cause economic and human health impacts: A review, Bull. Amer. Meteor. Soc., 80, 1077-1098, 1999.

Lookingbill, T. R. and Urban, D. L.: Spatial estimation of air temperature differences for landscape-scale studies in montane environments, Agric. For. Met., 114, 141-151, 2003.

Maoa, L., Cavalli, M., Comiti, F., Marchi, L., Lenzi, M. A., and Arattano, M.: Sediment transfer processes in two Alpine catchments of contrasting morphological settings, Journal of Hydrology, 364, 88-98, 2009.

Marchi, L., Arattano, M., and Deganutti, A. M.: Ten years of debrisflow monitoring in the Moscardo Torrent (Italian Alps), Geomorphology, 46, 1-17, 2002.

National-land information data: Ministry of Land, Infrastructure, Transport and Tourism, http://nlftp.mlit.go.jp/ksj/, 2001.

Palmer, T. N. and Raisanen, J.: Quantifying the risk of extreme seasonal rainfall events in a changing climate, Nature, 415, 512514, 2002.

Parry, M., Canziani, O., Palutikof, J., Linden, P.V., and Hanson, C.: Climate change 2007: Impacts, Adaptation and Vulnerability. Summary for policymakers, Cambridge University Press: New York; 11, 2007.

Philip, J. W., Balen, R. T., Verstraeten, G., Renssen, H., and Vandenberghe, J.: The impact of land use and climate change on late Holocene and future suspended sediment yield of the Meuse catchment, Geomorphology, 103, 389-400, 2009.

Restrepo, J., Kjerfe, B., and Hermelin, M.: Factors controlling sediment yield in a major South American drainage basin: the Magdalena River, Colombia, J. Hydrol., 316, 213-232, 2006.
Sakamoto, H.: Engineer for Dams, http://jglobal.jst.go.jp/detail. php?JGLOBAL_ID=200902243241683992 \\&q=\%E5\%9D\% $82 \% \mathrm{E} 6 \% 9 \mathrm{C} \% \mathrm{AC} \% \mathrm{E} 3 \% 80 \% 80 \% \mathrm{E} 7 \% 9 \mathrm{C} \% 9 \mathrm{~F} \% \mathrm{E} 5 \% 90 \% 8 \mathrm{D} \%$ $\mathrm{E} 5 \% \mathrm{~B} 7 \% 9 \mathrm{D} \backslash \& \mathrm{t}=0,2008$.

Salathe, Jr. E. P., Mote, P. W., and Wiley, M. W.: Review of scenario selection and downscaling methods for the assessment of climate change impacts on hydrology in the United States Pacific Northwest, Int. J. Climatology, 27, 1611-1621, 2007.

Shou, K., Chen, Y., and Liu, H.: Hazard analysis of Li-shan landslide in Taiwan, Geomorphology, 103, 143-153, 2009.

Suzuki, H.: Trend in the frequency of heavy rainfall events during the last half century over Japan, Tenki, 51, 805-816, 2004 (in Japanese).

Temesgen, B., Mohammed, M. U., and Korme, T.: Natural Hazard Assessment Using GIS and Remote Sensing Methods, with Particular Reference to the Landslides in the Wondogenet Area, Ethiopia, Phys. Chem. Earth (C), 26, 665-615, 2001.

Ueyama, H.: Estimation of air temperature distribution in Kamogawa by means of a stepwise multiple regression analysis using $50 \mathrm{~m}$ mesh topographical data, JASS 20, 53-63, 2004.

Waters, T. F.: Sediments in Streams: Sources, Biological Effects and Control, American Fisheries Society Monograph 7, 1995.

Westen, C. J., Rengers, N., and Soeters, R.: Use of geomorphological information in indirect landslide susceptibility assessment, Natural Hazards, 30, 399-419, 2003.

Westen, C. J., Seijmonsbergen, A. C., and Mantovani, F.: Comparing landslide hazard maps, Natural Hazards, 20, 137-158, 1999.

Wicks, J. M. and Bathurst, J. C.: SHESED: a physically based, distributed erosion and sediment yield component for the SHE hydrological modelling system, J. Hydrol., 175, 213-238, 1996.

Yilmazer, I., Yilmazer, O., and Sarac, C.: Case history of controlling a major landslide at Karandu, Turkey, Eng. Geology., 70, 47-53, 2007.

Xie, M., Tetsuro, E., Qiu, C., and Jia, L.: Spatial three-dimensional landslide susceptibility mapping tool and its applications, Earth Sci. Frontiers, 14, 73-84, 2007. 